for Darwin, whilst against them were ranged L. Agassiz, Le Conte, Hunt, Semper, and Rein. One might with equal justice claim for an eminent engineer that a bridge constructed by him as a young man in 1842 and repaired by him when an elderly man in I 874, represented the accumulated experience of a long professional career, notwithstanding that he had never since erected another bridge, and had devoted all his time to works of a very different character, and in spite of the fact that, whilst only two engineers of reputation had in the interval pronounced the bridge to be safe, five cthers of equal eminence bad advised that, owing to its rickety condition, it slould be pulled down. If it was a question of personal safety, most people would trust to the opinion of the many.

1 will first clear the way by laying stress on the circumstance that neither A. Agassiz nor Murray doubt the reality of subsid ence. They only contend that the characteristic form of atolls and barrier reefs is not dependent on it, and that such reefs would be preduced by their natural mode of growth alone.

Now, with regard to Fiji, Captain Moore is perhaps not aware that in the writings of Murray, Semper, Geikic, and others, in these columns and elsewhere, the association of the three classes of reefs in the same group, as in Fiji, has often been referred to as opposed to the theory of subsidence. It was the occurrence of all reefs in the Fijis and in the Pelew Group, and the ascertained existence of upraised reefs in the last locality, that amongst other reasons led Murray and Semper to find some different explanation than that of subsidence. Dana saw the difficulty, and tried to avoid it by asserting that small fringing reefs are "often evidence of subsidence, even a greater subsidence than is implied by barrier reefs" (Amer. Fourn. Science and Arts, 3rd series, vol. viii., p. 316). Semper, however, pointed out that this conclusion at once destroyed the value of the testimony afforded by coral reef of the movements of the earth's crust, since, if all kinds of reefs can be formed during subsidence, the character of a reef cannot guide us in determining the existence of subsidence or upheaval ("Animal Life," p. 233). Darwin also saw the difficulty of the Pelew Group, where living atolls, barrier reefs, and fringing reefs were associated with upraised ancient reefs; and thus it came about that, when writing to Semper in 1879 , he generously observed that, although he still adhered to the theory of subsicience, such cases as that of the Pelew Islands, if of at all frequent occurrence, would make his conclusions of very little value. "Future observers," he went on to say, "must decide between us," \&c. (Semper's "Animal Life," p. 456).

I contend that in I $889 \mathrm{Mr}$. Darwin's condition has already been realized, since we have in the interval proved that in respect to the occurrence in the same locality of all three classes of coral reefs and their association with ancient upraised reefs; the Fijis, the Tongan Group, and the Solomon Islands are but reproduc tions of the Pelew Group. It will therefore be seen that Captain Moore is in error when he believes that Darwin would not have regarded simultareous up and down movements in the same group as inconsistent with his theory. Darwin's admission to Prof. Semper in the case of the Pelews shows plainly enough what he would have thought of the Fijis. This difficulty of imagining simultaneous up and down movements in the same group was also perceived by the present Director-General of the Geological Survey, when he remarked some years ago in these columns that " such an association of upheaval with an assumed general subsidence requires, on the subsidence theory, a cumbrous and entirely hypothetical series of upward and downward movements" (NA'TuRe, vol. xxix. p. IO7; Proc. Roy. Phys. Soc., viii.)

It is somewhat remarkable that long as the Fiji Group has been known, it is only of recent years that anything has been published concerning its upraised coral reefs and its other evidences of considerable upheaval. Darwin, as late as his edition of 1874 , knew nothing of the extensively upraised reefs, and he still coloured the group in his map as in an area of subsidence. Strangely enougb, amongst the many errors perpetuated in the edition published in the present year of Mr. Darwin's work, is that relating to this group. In an additional footnote (p. 215) we find no reference to the ancient coral reefs upraised some hundreds of feet in the Lat or Windward Group, which are referred to in the Hydrographic publication of 1882 concerning Fiji, and which were described to me by Lieut. Malan some years ago. We find no reference in this edition of 1889 to the conclusion of Mr. Brady that the Suva soapstone, as indicated by its Foraminifera, was formed in depths of from 150 to 200 fathoms in post-Tertiary times, thus implying an upheaval of from 900 to 1200 feet
(Geol. Soc., November 9, 1887). Curious as it may appear, Dana, after his lengthened stay in the group, found proofs of an elevation in the larger islands of only 5 or 6 feet, and was inclined to negative it altogether in the case of the eastern islands ("Corals and Coral Islands," I872, pp. 342, 346).

Captain Moore refers to the "many evidences of uplueaval" in Fiji, and instances the occurrence of shells and coral "at great heights." What evidence has he of subsidence? He points to the form of the reef in varions islands, and thus assumes the very question at issue. However, I will leave to Mr. Murray to explain how these reefs attained their characteristic form without the assumed movement of subsiclence, of which in fact we can find no direct proof.

H. B. Guppy.

As Dr. Guppy asks for information with regard to the corals found living at the greater depihs round islands in the Indian and Pacific Oceans the following may be of interest.

About two years ago Capt. Wharton, F.R.S., called attention to the Tizard Bank, and last year both it and the Macclesfield Banks were examined by H.M.S. Kambler.

The further investigation of the material sent home has shown that the large number of eighteen genera with forty species were found living in depths from $20-44$ fathoms outside the reefs, and these species differed with but few exceptions from those in the shallow water.

The following ten genera were found at a greater depth than 30 fathoms-Stylophora, Astræa, Pavonia, Cycloseris, Leptoseris, Stephanaria, Psammocora, Montipora, Alveopora, and Rhodaræa, besides seven small scarcely reef-building genera.

The total number of speciss collected was 142 , so that nearly one-third were represented in over 20 fathoms.

Y'. W. BASSETT-SMlTH, R.N.

\section{Hibernation of Martins in the Argentine Republic.}

Prof. Carlo Spegazzint, an Italian botanist, and quite a trustworthy observer, living at La Plata, the new town in the Argentine Republic, writes from there the following account to my friend the Marquis Giacomo Doria of Genoa :-

"The bird known here by the name of Golondrina, and which I think is Progne domestica, ${ }^{1}$ is subject to hibernation. Last year, while the zinc roof of a smali house was being taken up in the month of August, just in the middle of our winter, I found underneath about a hundred martins, all accumulated one over the other and lethargic, but in good health, so that, exposed to the sun, they awoke and flew away very briskly. This year, again, having seen some holes on a barrancha, a steep bank over the Plata, I began to dig at them, hoping to find some bats; but there $I$ found several hundreds of the martins of the same kind as above mentioned, clustered and in a state of lethargy. Is such a thing known to naturalists?"

Zoological Museum, Turin, June I8

Tommaso Salvadori.

\section{Atmospheric Electricity.}

THE interesting accounts of certain electrical phenomena of the atmosphere in NATURE of May 16,23 , and 30 , lead me to state that it is a common experience of surveying parties, es. pecially on the high peaks and slopes in the western part of this country to underyo these peculiar electrical sensations. In general these may be described as tingling or pricking sensations, accompanied with hissing or crackling sounds, especially marked if a finger be presented to any metallic object near by. But further than this it has been noticed that whenever a flash of lightning occurs there is a sudden cessation of the distressing electrical effects. The explanation of this is, we think, found in sorne experiments made at the top of the Washington Monument (elevation 500 feet) during thunderstorms. With a "water dropper collecter," Mascart insulators and quadrant electrometer, we measured the difference of the electrical potential of the air and the ground. The electrometer needle becomes very active with the approach of the "thunder-heads," and after considerable oscillation begins to move steadily in one direction as if subjected to a steadily increasing "pull," and then suddenly, when a potential difference of severa! thousand volts may be indicated, there is an "instant" drop to zero, and apparent rebound in the other direction, not due to the torsion of the 'Or more likely Progne shalybaa, Gm.-T. S. 